\title{
ANALISIS SKEMA ALTERNATIF KREDIT PROGRAM UNTUK USAHA MIKRO, KECIL, DAN MENENGAH
}

\author{
(An Analysis on Alternative Schemes of Credit Program for Small and Medium Enterprises) \\ Abdul Aziz* dan Eko Wicaksono** \\ Pusat Kebijakan APBN Badan Kebijakan Fiskal, Kementerian Keuangan \\ Gedung R. M. Notohamiprodjo, Lantai 6, Jl. Dr Wahidin 1, Jakarta \\ *Email: kingabaz@gmail.com \\ **Email: wicaksono.eko@gmail.com \\ Naskah diterima: 20 Januari 2016 \\ Naskah direvisi: 15 Februari 2016 \\ Naskah diterbitkan: 30 Desember 2016
}

\begin{abstract}
The Indonesian government is committed to lower down the poverty rate over time. The provision of credit program scheme is one of the programs aimed to assist small and medium enterprises (SMEs) to have broader access to the scheme. Currently, two schemes of the credit program are available for the SMEs: interest rate subsidy scheme and guaranteed scheme. Both of the schemes encounter several challenges in their implementation. Default risk of the creditor, high prudentiality of the executing banks as well as poorly targeted beneficiaries were the problems arising in credit program provision, thus leading to unoptimized use of the available fund. Those problems were associated with the basic problems in credit market: asymmetric information and moral hazard. Therefore, in this study, we would like to propose an alternative scheme as an improvement for that program. Microfinance institutions can be the solution to that problem since they have better access to borrowers compared to executing banks. In other words, the basic problems in credit market could be diminished by developing this particular institution. In this alternative model we emphasize the important role the microfinance institutions could play. By empowering microfinance institutions, it is expected that credit market for small borrowers can be developed, thus leading to greater access to credit for them.

Keywords: credit program, credit access, small and medium enterprises, microfinance institution
\end{abstract}

\begin{abstract}
Abstrak
Pemerintah Indonesia memiliki komitmen untuk mengurangi angka kemiskinan di Indonesia. Salah satu program kegiatan yang digulirkan adalah dengan pemberian fasilitas kredit kepada unit usaha mikro, baik melalui skema penjaminan kredit seperti Kredit Usaha Rakyat (KUR) maupun melalui skema subsidi bunga seperti Kredit Ketahanan Pangan dan Energi (KKP-E) dan Kredit Usaha Pembibitan Sapi (KUPS). Namun demikian, terdapat permasalahan besar dalam implementasi, seperti besarnya risiko terjadinya default, prudentiality dari bank pelaksana yang terlalu tinggi, serta ketidaktepatan penyaluran. Permasalahan tersebut tidak terlepas dari permasalahan dasar di credit market, yaitu asymmetric information yang meliputi adverse selection dan moral hazard. Oleh sebab itu, permasalahan ini pada akhirnya berujung pada tidak optimalnya penyerapan kredit program. Hal tersebut akan menghambat akses calon debitur kepada permodalan pada waktu yang tepat, sehingga tidak menutup kemungkinan calon debitur tersebut akhirnya mengandalkan akses modal dari lembaga keuangan informal dengan tingkat bunga yang cukup tinggi. Potret permasalahan tersebut mendasari penelitian ini untuk menganalisis lebih lanjut desain alternatif skema kredit program. Skema tersebut mencakup institusi yang seharusnya dilibatkan dalam implementasi program sehingga terwujud credit market yang berkelanjutan bagi usaha mikro, kecil, dan menengah (UMKM). Keberadaan lembaga keuangan mikro (LKM) dianggap dapat mengatasi kedua permasalahan dasar tersebut mengingat LKM memiliki akses informasi yang lebih bagus terkait calon debitur. Oleh sebab itu, salah satu rekomendasi yang diajukan adalah melakukan penyatuan format kredit program dan pada akhirnya mengusulkan LKM sebagai salah satu pelaksana dari kredit program untuk memperluas akses kredit bagi UMKM di Indonesia.
\end{abstract}

Kata kunci: kredit program, akses permodalan, UMKM, LKM

\section{PENDAHULUAN}

\section{A. Latar Belakang}

Pemerintah Indonesia telah lama menjalankan program pengurangan kemiskinan, yaitu dengan memberikan bantuan sosial, baik secara langsung melalui program cash transfer maupun tidak langsung melalui subsidi bagi masyarakat miskin. Dalam hal program pemberdayaan masyarakat berpenghasilan rendah khususnya bagi mereka yang mengelola unit usaha pemerintah telah memberikan dukungan akses permodalan dengan biaya rendah. Kredit program menjadi salah satu cara untuk memperluas akses permodalan bagi para pengusaha kecil seperti petani, nelayan, pedagang kecil, dan pekerja di sektor informal. Melalui program tersebut calon debitur dapat memperoleh keringanan, baik berupa suku bunga kredit yang lebih rendah dari bunga pasar (skema subsidi bunga) maupun keringanan dalam memenuhi persyaratan collateral/jaminan. Sejak tahun 20082015, pemerintah telah menjalankan berbagai jenis penyaluran kredit program seperti Kredit Ketahanan Pangan dan Energi (KKP-E), Kredit Pengembangan Energi Nabati dan Revitalisasi Perkebunan (KPEN-RP), dan Kredit Usaha Pembibitan Sapi (KUPS) untuk skema subsidi bunga, serta Kredit Usaha Rakyat (KUR) untuk skema penjaminan. Kedua jenis skema kredit tersebut 
Tabel 1. Model dan Jenis Kredit Program Sektor Pertanian

\begin{tabular}{lll}
\hline \multicolumn{1}{c}{$\begin{array}{c}\text { Penjaminan } \\
\text { Risiko }\end{array}$} & \multicolumn{1}{c}{ Subsidi Bunga } \\
\hline & 1. & Kredit Pengembangan Energi Nabati dan \\
& Revitalisasi Perkebunan (KPEN-RP); \\
& 2. & Kredit Usaha Pembibitan Sapi (KUPS); \\
Kredit Usaha & 3. & Kredit Ketahanan Pangan dan Energi \\
Rakyat (KUR) & (KKP-E); \\
& 4. & Kredit Pemberdayaan Pengusaha \\
& NAD dan Nias (KPP NAD-Nias) Korban \\
& Bencana Alam Gempa dan Tsunami; \\
& 5. & Subsidi Resi Gudang (SRG). \\
\hline
\end{tabular}

Sumber: Arifin, 2013; dan Aziz, 2013 (diolah).

disalurkan melalui bank yang berperan sebagai executing agent dalam penyaluran kredit program.

Secara garis besar dukungan akses permodalan pemerintah melalui kredit program tersebut dapat dikelompokkan ke dalam 2 model skema pembiayaan kredit yaitu skema/model penjaminan risiko dan skema/model subsidi bunga seperti tampak pada Tabel 1.

Kredit program dengan skema subsidi bunga adalah kredit yang diberikan kepada para calon debitur yang dianggap not feasible but bankable. Salah satu persyaratan utama pada kredit program dengan skema subsidi bunga adalah penyediaan jaminan dari calon debitur kepada bank pelaksana. Meskipun mampu menyediakan jaminan, namun, usaha dari calon debitur tersebut dianggap belum dapat menutupi kewajiban pembayaran bunga dan mengembalikan seluruh hutang pokok kredit/ pembiayaan dalam jangka waktu yang disepakati antara bank pelaksana dengan debitur tersebut (Tim Pelaksana Komite Kebijakan Penjaminan Kredit/ Pembiayaan, 2012).

Sedangkan kredit program dengan skema penjaminan ditujukan untuk para calon debitur yang mempunyai karakteristik not-bankable tetapi sudah feasible. Kredit dengan skema tersebut diperuntukkan bagi calon debitur yang belum memenuhi persyaratan perkreditan/pembiayaan dari bank pelaksana dalam hal penyediaan agunan dan pemenuhan persyaratan perkreditan/pembiayaan lainnya sesuai dengan ketentuan bank pelaksana. Hal tersebut terjadi karena para calon debitur (khususnya petani) tidak mempunyai dana untuk membiayai usahanya sendiri dan memiliki modal yang cukup (Ashari, 2009) meskipun pada dasarnya calon debitur tersebut dianggap feasible.

Namun, beberapa kendala dan masalah muncul dalam penyaluran kredit program tersebut mulai dari ketepatan target sasaran sampai dengan rendahnya penyerapan pinjaman kredit program. Pertama, kredit program merupakan program pemerintah yang seringkali disalahartikan sebagai pinjaman cuma-cuma dari pemerintah kepada penerimanya sehingga dapat menimbulkan niat bagi para debitur untuk tidak membayar cicilan pokok dan bunga yang berakhir pada default. Kedua, adanya kredit dengan bunga rendah akan menimbulkan overdemand pada jenis kredit tersebut sehingga timbul risiko tidak tepat sasaran penerima kredit mengingat besarnya permintaan pasar akan jenis kredit tersebut.

Tabel 2 menunjukkan variasi kredit program yang telah dan sedang dijalankan oleh pemerintah dengan berbagai potensi masalah yang muncul.

Tabel 2. Kredit Program di Indonesia yang Telah Berjalan

\begin{tabular}{|c|c|c|}
\hline $\begin{array}{c}\text { Kredit } \\
\text { program }\end{array}$ & Ketentuan/aturan & Permasalahan \\
\hline KKP-E & $\begin{array}{l}\text { - Sumber dana } \\
\text { dan penyalur: } \\
\text { bank pelaksana } \\
\text { - Target: petani/ } \\
\text { poktan/ } \\
\text { gapoktan/ } \\
\text { koperasi } \\
\text { Skema: Subsidi } \\
\text { bunga }\end{array}$ & $\begin{array}{l}\text { Persyaratan agunan } \\
\text { yang memberatkan } \\
\text { petani } \\
\text { - } \quad \text { Proses pengajuan } \\
\text { dan penyaluran KKP-E } \\
\text { yang cukup lama } \\
\text { Minimnya peran } \\
\text { dinas/penyuluh } \\
\text { - Realisasi rendah }\end{array}$ \\
\hline KPEN-RP & $\begin{array}{l}\text { - Sumber dana } \\
\text { dan penyalur: } \\
\text { bank pelaksana } \\
\text { - Target: petani/ } \\
\text { pekebun/ } \\
\text { kelompok/ } \\
\text { koperasi } \\
\text { - Skema: Subsidi } \\
\text { bunga }\end{array}$ & $\begin{array}{l}\text { - Terkait dengan } \\
\text { lahan/Rencana } \\
\text { Tata Ruang Wilayah } \\
\text { (RTRW) yang belum } \\
\text { jelas } \\
\text { - Terbatasnya jumlah } \\
\text { perusahaan yang } \\
\text { menjadi mitra inti } \\
\text { Lambatnya proses } \\
\text { penetapan daftar } \\
\text { nominatif petani di } \\
\text { tingkat kabupaten } \\
\text { Realisasi rendah }\end{array}$ \\
\hline KUPS & $\begin{array}{l}\text { - Sumber dana } \\
\text { dan penyalur: } \\
\text { bank pelaksana } \\
\text { - Target: } \\
\text { Perusahaan } \\
\text { pembibitan/ } \\
\text { kop/ kelompok } \\
\text { peternak sapi } \\
\text { Skema: Subsidi } \\
\text { bunga }\end{array}$ & $\begin{array}{l}\text { - Suku bunga yang } \\
\text { fluktuatif } \\
\text { - } \text { Risiko usaha yang } \\
\text { cukup tinggi } \\
\text { - } \quad \text { Birokrasi yang lama } \\
\text { dan biaya tinggi } \\
\text { - Pembinaan yang } \\
\text { kurang } \\
\text { - } \text { Realisiasi rendah }\end{array}$ \\
\hline KUR & $\begin{array}{l}\text { - Sumber dana } \\
\text { dan penyalur: } \\
\text { bank pelaksana } \\
\text { - Target: UMK } \\
\text { seluruh sektor } \\
\text { - Skema: } \\
\text { Penjaminan }\end{array}$ & $\begin{array}{l}\text { - Masih terdapat salah } \\
\text { sasaran } \\
\text { - Bank masih } \\
\text { mewajibkan agunan } \\
\text { meskipun pada } \\
\text { debitur KUR Mikro }\end{array}$ \\
\hline
\end{tabular}

Sumber: berbagai sumber (diolah). 


\section{B. Permasalahan}

Sesuai dengan kerangka teori ekonomi, bahwa terdapat dua masalah utama dalam imperfect credit market, yaitu moral hazard dan adverse selection. Menurut Armendariz de Aghion \& Morduch (2005), masalah moral hazard muncul ketika pemberi pinjaman, dalam hal ini bank, tidak dapat memastikan bahwa peminjam/debitur akan berusaha semaksimal mungkin untuk memastikan investasi yang mereka lakukan akan berhasil. Masalah ini akan timbul apabila debitur tidak secara cermat menggunakan dana yang telah diberikan untuk kegiatan yang produktif dengan risiko yang minimal sehingga akan berimplikasi pada pembayaran pokok hutang dan bunganya. Dari sisi bank, moral hazard dapat timbul apabila bank atau lembaga penyalur memiliki kecenderungan untuk menyalurkan pinjaman kepada kelompok debitur tertentu yang memiliki kedekatan dengan pihak bank. Sedangkan masalah kedua, adverse selection, muncul ketika pemberi pinjaman tidak dapat membedakan dengan jelas manakah peminjam yang memiliki risiko default tinggi dan rendah.

Semua jenis kredit program yang telah dijalankan oleh pemerintah ditujukan untuk meningkatkan output dari sektor pertanian, seperti misalnya KKP-E yang ditujukan untuk mendukung program ketahanan pangan dan energi melalui pengusahaan tanaman pangan dan bahan baku bahan bakar nabati. Akan tetapi, sebenarnya usaha pemerintah untuk mengarahkan penggunaan pinjaman untuk usaha di sektor tertentu seperti pertanian justru akan kontra produktif dengan pengembangan pasar keuangan dan pengentasan kemiskinan di daerah perdesaan (Adams, et al., 1984). Menurut mereka, adanya dukungan pemerintah dalam bentuk subsidi justru akan menyebabkan masalah pada pasar keuangan di perdesaan sehingga lembaga keuangan yang diberi subsidi akan menguasai pasar dan membuat lembaga keuangan lainnya yang tidak mendapatkan subsidi menjadi tersisih, seperti lembaga keuangan informal.

Lebih lanjut, menurut Armendariz de Aghion \& Morduch (2005) terdapat beberapa kritik terhadap kredit bersubsidi. Pertama, selama ini banyak masyarakat miskin yang bergantung pada jasa lembaga keuangan informal karena keterbatasan akses mereka terhadap lembaga keuangan formal seperti bank. Keberadaan lembaga keuangan bersubsidi dianggap akan melemahkan keberadaan lembaga keuangan informal yang ada saat ini. Kedua, bunga pasar merupakan salah satu rationing mechanism karena mereka yang bersedia untuk membayar pinjaman adalah mereka yang memiliki usaha dengan prospek bagus. Adanya bunga rendah di bawah bunga pasar dapat menimbulkan kemungkinan pinjaman dialokasikan kepada mereka yang memiliki prospek kurang bagus karena adanya motif sosial dan politik. Ketiga, adanya aliran dana dari pemerintah dapat menurunkan insentif bank untuk menghimpun dana dari masyarakat, sehingga masyarakat miskin tidak memiliki sarana untuk menyimpan dana mereka. Keempat, adanya subsidi khususnya kepada bank milik pemerintah dapat memberikan tekanan kepada bank tersebut untuk memutihkan pinjaman untuk tujuan politik seperti pada saat menjelang pemilihan umum dan kurang memberikan insentif kepada mereka untuk menjadi institusi yang dapat beroperasi dengan efisien.

Permasalahan penyaluran kredit program di Indonesia saat ini juga tidak terlepas dari masalah adverse selection dan moral hazard. Kedua masalah tersebut berujung pada semakin tingginya bunga yang harus ditanggung oleh calon debitur, khususnya mereka yang berpenghasilan rendah dan tidak memiliki harta yang akan dijaminkan. Hal tersebut juga dapat terlihat dari rendahnya penyaluran pada beberapa jenis kredit program. Selain itu tidak menutup kemungkinan penyalahgunaan kredit program tersebut oleh mereka yang sebenarnya tidak berhak. Dengan kata lain, terdapat ketidaktepatan sasaran pada penyaluran kredit tersebut.

Lebih lanjut, kondisi pasar permodalan di daerah perdesaan juga masih belum berkembang dengan baik meskipun sebenarnya potensi dana yang ada di perdesaan saat ini dapat dioptimalkan untuk digunakan oleh masyarakat desa. Pengembangan infrastruktur pasar permodalan tersebut seharusnya perlu diperhatikan oleh pemerintah sehingga dapat digunakan oleh masyarakat desa untuk meningkatkan pendapatan dan terhindar dari jurang kemiskinan. Oleh karena itu, perlu untuk diperhatikan pula pengembangan institusi yang dapat mendukung peningkatan akses permodalan bagi masyarakat berpenghasilan rendah di perdesaan.

Berdasarkan permasalahan tersebut, kajian ini berusaha untuk merekomendasikan skema alternatif kredit program yang idealnya diterapkan oleh pemerintah di masa yang akan datang. Beberapa permasalahan utama yang akan dibahas adalah gambaran keunggulan dan kekurangan institusi yang menjadi pelaksana kredit program serta model skema alternatif kredit program yang ideal dan berkelanjutan untuk diterapkan di Indonesia di masa yang akan datang.

\section{Tujuan}

Tujuan dari penelitian ini adalah untuk memberikan sebuah evaluasi atas pelaksanaan kredit program di Indonesia saat ini beserta usulan perbaikan dari penerapan kredit program tersebut, khususnya terkait dengan skema penyaluran kredit program. Beberapa 
hal utama yang akan dibahas dalam kajian ini adalah pemetaan keunggulan dan kelemahan dari instansi alternatif yang diusulkan sebagai penyelenggara kredit program serta usulan beberapa model skema alternatif kredit program.

\section{KERANGKA TEORI}

Pengentasan kemiskinan merupakan salah satu tantangan utama yang dihadapi negara berkembang seperti Indonesia. Kemiskinan akan menghambat perkembangan serta memperkecil peluang penduduk dengan penghasilan kecil untuk memperbaiki kualitas hidup mereka. Salah satu faktor yang dianggap berperan penting dalam membantu penduduk berpenghasilan rendah keluar dari jebakan kemiskinan adalah adanya akses keuangan yang memadai. Akses keuangan yang memadai dapat mendorong masyarakat berpenghasilan rendah untuk mengubah aktivitas produktif mereka untuk keluar dari kemiskinan (Banerjee \& Newman, 1993; Aghion \& Bolton, 1997; Banerjee, 2003) dalam (Burgess \& Pande, 2005).

Masyarakat berpenghasilan rendah, khususnya di kawasan perdesaan, cenderung memiliki akses yang kecil terhadap institusi keuangan apabila dibandingkan dengan masyarakat di daerah perkotaan. Akses yang terbatas tersebut juga menjadi salah satu penghambat untuk keluar dari kemiskinan. Beberapa studi yang telah dilakukan sebelumnya menunjukkan bahwa besarnya akses keuangan berpengaruh pada tingkat kemiskinan pada suatu daerah. Swain (2002) menemukan bahwa jumlah institusi keuangan formal di perdesaan masih sangat sedikit meskipun sebenarnya permintaan akan akses permodalan di daerah tersebut cukup tinggi. Selanjutnya, Burgees \& Pande (2005) menemukan bahwa dibukanya institusi keuangan seperti bank di perdesaan mampu menurunkan tingkat kemiskinan di kawasan tersebut. Namun, mekanisme penyaluran kredit juga sangat penting untuk diperhatikan sebagaimana (Karlan \& Morduch, 2009) sebutkan bahwa mekanisme penyaluran kredit yang meliputi desain produk keuangan akan berpengaruh pada penggunaan dana dan dampak sosial yang ditimbulkan.

Pengembangan institusi microfinance telah menjadi salah satu bentuk inovasi dan solusi dalam memperluas akses kredit khususnya kepada masyarakat miskin. Ketika akan melayani masyarakat miskin terdapat 2 masalah utama yang dihadapi oleh lembaga keuangan formal seperti bank, yaitu (1) tidak adanya jaminan yang dimiliki oleh calon debitur miskin, dan (2) sulitnya penegakan kontrak (contract enforcement) dengan debitur miskin. Kedua hal tersebut berawal dari minimnya informasi yang dimiliki oleh bank terkait kondisi calon debitur miskin. Berdasarkan pengalaman di negara berkembang seperti Bangladesh, institusi microfinance memiliki kelebihan yang tidak dimiliki oleh bank pada kedua hal tersebut. Institusi microfinance memiliki beberapa informasi lebih terkait kondisi debitur sehingga mampu untuk mengatasi kedua masalah yang dimiliki oleh bank ketika berhadapan dengan debitur miskin.

Sebagai salah satu contoh adalah penerapan group lending oleh Grameen Bank di Bangladesh (Mainsah, et al., 2004). Melalui group lending tersebut para calon debitur dipersilakan untuk mengajak beberapa calon debitur lainnya yang dianggap bagus untuk kemudian membentuk sebuah kelompok debitur. Setiap anggota kelompok nantinya akan bertanggung jawab apabila ada salah satu di antara mereka yang default. Mekanisme akan memberikan beberapa keuntungan kepada Grameen Bank. Pertama, biaya yang diperlukan untuk menggali informasi dari calon debitur dapat diminimalkan karena calon debitur akan memiliki insentif untuk mencari calon debitur lain yang mereka anggap layak dan mampu. Kedua, risiko default dari debitur juga dapat diminimalkan karena setiap anggota kelompok bertanggung jawab terhadap kelancaran pembayaran oleh anggota lainnya dalam kelompok tersebut.

Lebih lanjut, subsidi dapat digunakan untuk mendukung pengembangan microfinance. Penggunaan subsidi sebagai salah satu alat untuk meningkatkan akses keuangan bagi masyarakat miskin haruslah melalui perencanaan yang baik sehingga berbagai masalah klasik seperti ketepatan sasaran maupun distorsi pasar dapat dihindari. Subsidi akan lebih tepat digunakan sebagai sarana pemenuhan barang publik (public goods) di mana hampir tidak terdapat insentif bagi seseorang untuk mengadakan atau memproduksi barang tersebut. Subsidi seharusnya juga hanya diberikan dalam jangka waktu tertentu yang terbatas sehingga tidak mendorong pada munculnya ketergantungan penerimanya terhadap subsidi.

Menurut Armendariz de Aghion \& Morduch (2005), salah satu bentuk intervensi pemerintah yang tepat adalah melalui pemberian "smart subsidy", yaitu subsidi yang mampu meminimalkan distorsi, inefisiensi, dan mampu memaksimalkan manfaat sosial. Salah satu bentuk subsidi tersebut adalah subsidi terhadap institusi. Tingginya biaya yang harus ditanggung oleh institusi microfinance akan dibebankan pula kepada para debiturnya. Melalui "smart subsidy" pemerintah dapat memberikan subsidi atas start up cost dari institusi microfinance tersebut, sehingga biaya yang dibebankan kepada debitur dapat diminimalkan. Salah satu hal yang perlu ditekankan di sini adalah subsidi terhadap start up cost bukan pada biaya operasi sehari-hari sehingga hanya akan diberikan pada jangka waktu tertentu yang terbatas. 


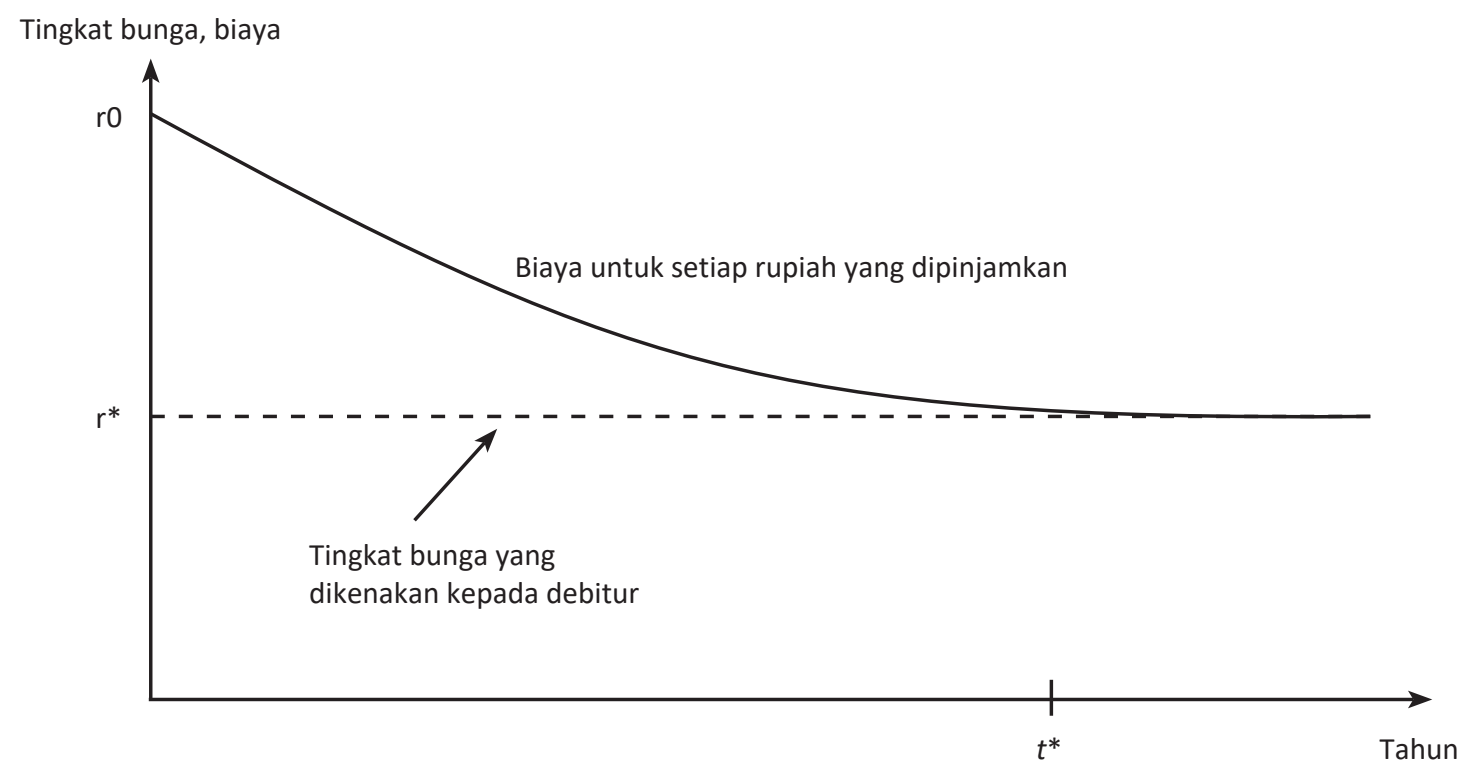

Sumber: Armendariz de Aghion \& Morduch, 2005.

\section{Gambar 1. Start Up Cost Subsidy}

Gambar 1 menunjukkan bagaimana subsidi dengan pola tersebut berpengaruh terhadap beban bunga yang ditanggung oleh debitur seiring berjalannya waktu. Pada awal operasi, tingkat bunga yang dikenakan kepada debitur ( $r 0$ ) lebih tinggi daripada tingkat bunga dalam jangka panjang $\left(r^{*}\right)$. Subsidi diberikan pemerintah untuk membantu institusi microfinance pada awal beroperasi untuk menekan start up cost sehingga bunga yang dikenakan kepada debitur dapat lebih rendah dan sesuai dengan tingkat suku bunga di masa yang akan datang $\left(r^{*}\right)$.

\section{METODOLOGI}

Untuk menjawab permasalahan dan tujuan penelitian maka metodologi penelitian yang digunakan melalui deskriptif dan kualitatif. Metode deskriptif dilakukan dengan pengumpulan data sekunder tentang instansi yang relevan sebagai pelaksana alternatif kredit program di masa yang akan datang.

\section{A. Metode Pengumpulan Data}

Data yang akan digunakan dalam penelitian ini diperoleh melalui (a) studi literatur melalui studi pustaka dan jaringan internet terhadap materi terkait kredit program termasuk best practices di beberapa negara yang melaksanakan program serupa dan (b) Focus Group Discussion dengan beberapa narasumber terkait seperti SMERU Research Institute, Kementerian Pertanian, dan Kementerian Keuangan.

\section{B. Metode Analisis}

Metode analisis yang digunakan dalam penelitian ini adalah deskriptif kualitatif, yaitu menampilkan secara kualitatif dan deskriptif hasil pengolahan datadata yang diperoleh sehingga menjawab tujuantujuan dari penelitian ini.

\section{HASIL DAN PEMBAHASAN}

A. Review atas Skema Kredit Program yang Ada Selama Ini di Indonesia

\section{Skema Subsidi Kredit Program}

\section{Skema Penjaminan}

Skema ini digunakan pada penyaluran KUR. Pada skema ini pemerintah memberikan penjaminan sebesar 70 persen s.d. 80 persen dari risiko kredit melalui perusahaan penjaminan. Skema penjaminan ditujukan bagi calon debitur yang feasible namun unbankable. Dengan kata lain, skema ini ditujukan bagi para debitur yang mampu untuk memenuhi kewajiban pembayaran pinjaman namun mereka tidak mampu memenuhi persyaratan jaminan yang dipersyaratkan oleh bank.

Dalam kurun waktu lima tahun terakhir realisasi KUR relatif baik apabila dibandingkan dengan kredit program dengan skema subsidi bunga. Penyerapan anggaran untuk Imbal Jasa Penjaminan (IJP) KUR selama lima tahun terakhir cukup baik bahkan mencapai 100 persen pada tahun 2011-2013 (Gambar 2). Beberapa kelebihan dari skema ini adalah adanya keringanan bagi para calon debitur terkait dengan persyaratan jaminan yang harus dipenuhi ketika akan mengajukan kredit. Adanya penjaminan oleh pemerintah juga dapat memberikan keyakinan lebih kepada pihak bank untuk menyalurkan dananya kepada debitur. Selain itu, bagi pemerintah risiko fiskal yang dapat muncul dari fluktuasi tingkat bunga pasar dapat dihindari, mengingat pemerintah hanya memberikan subsidi pada imbal jasa penjaminan, bukan selisih tingkat bunga kredit program dengan tingkat bunga pasar.

Namun demikian, di sisi lain skema penjaminan juga memiliki beberapa kelemahan. Pertama, tingkat bunga yang harus ditanggung oleh debitur jauh lebih 


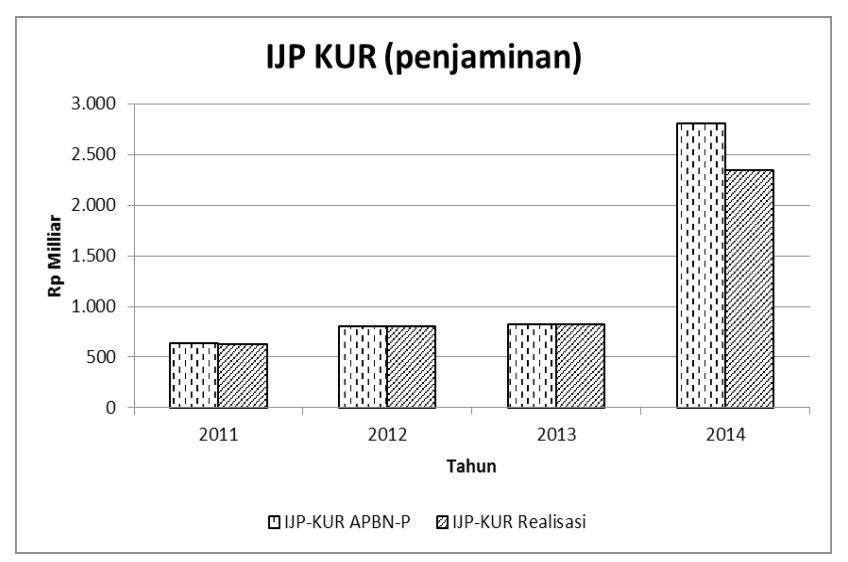

Sumber: Kementerian Keuangan, 2015.

Gambar 2a. Realisasi IJP KUR

tinggi daripada tingkat bunga kredit program dengan skema subsidi bunga. Kedua, kredit program sebagai program pemerintah juga tidak lepas dari risiko moral hazard, terlebih apabila pemerintah menjamin sebagian besar dari risiko default/gagal bayar yang dimiliki oleh debitur.

\section{Skema Subsidi Bunga}

Skema ini diterapkan pada pemberian sebagian besar kredit program seperti KUPS, KKP-E, KPENRG, dan S-SRG. Skema ini merupakan kebalikan dari skema penjaminan di mana target penerimanya adalah calon debitur yang not feasible namun bankable, yaitu bagi mereka yang memiliki kendala dalam memenuhi kewajiban pembayaran bunga pinjaman namun memiliki cukup jaminan sebagai persyaratan dalam mengajukan kredit. Pada skema ini pemerintah memberikan keringanan kepada para penerima yaitu berupa subsidi bunga yang besarnya ditinjau tiap kurun waktu tertentu.

Skema ini memiliki beberapa kelebihan, salah satunya, yaitu adanya keringanan bagi debitur dalam memenuhi kewajiban pembayaran bunga. Skema ini akan bermanfaat bagi debitur yang baru memulai usahanya sehingga adanya subsidi bunga dapat membantu pengusaha tersebut untuk menghasilkan keuntungan pada masa awal usahanya. Selain itu, adanya jaminan yang diberikan kepada bank juga akan miminimalkan risiko moral hazard dari debitur, sehingga mereka akan berusaha dengan sungguh-sungguh untuk memenuhi kewajiban pembayaran pinjamannya.

Namun, penyerapan anggaran untuk kredit program dengan skema subsidi bunga ini cenderung lebih rendah apabila dibandingkan dengan realisasi kredit program dengan skema penjaminan. Hal tersebut dapat dikaitkan dengan persyaratan jaminan yang harus dipenuhi oleh debitur ketika akan mengajukan pinjaman dengan skema subsidi bunga. Jaminan yang harus diberikan nilainya lebih besar dari pada nilai pinjaman yang diajukan sehingga persyaratan ini dapat memberatkan para petani

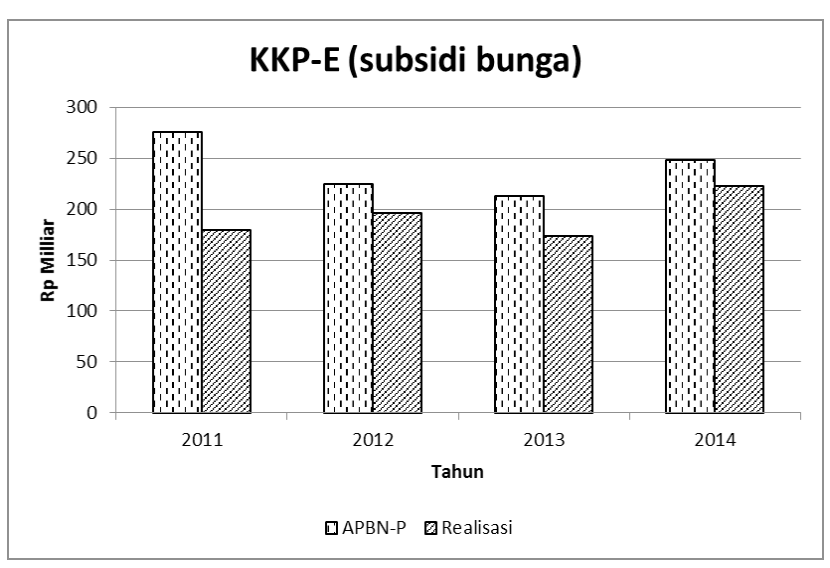

Sumber: Kementerian Keuangan, 2015.

Gambar 2b. Realisasi KKP-E

yang sebagian besar merupakan penerima kredit program. Selain itu, kehati-hatian berlebih dari pihak bank juga memengaruhi penyerapan kredit program dengan skema subsidi bunga. Hal tersebut wajar mengingat bank pelaksana bisa jadi tidak memiliki informasi menyeluruh terkait kondisi dari debitur sehingga mensyaratkan jaminan dengan nilai relatif tinggi untuk menghindarkan mereka dari risiko gagal bayar debitur.

Terkait dengan subsidi yang diberikan oleh pemerintah, skema subsidi bunga memiliki beberapa kekurangan. Pertama, fluktuasi tingkat suku bunga pasar dapat menyebabkan timbulnya risiko fiskal apabila subsidi bunga yang diberikan pemerintah tidak tetap. Kedua, program akan cenderung bersifat permanen apabila tidak ada batasan sampai dengan kapan subsidi bunga akan diberikan kepada penerimanya.

\section{Institusi Pelaksana/Penyalur}

Selama ini, instansi pelaksana/penyalur kredit program adalah perbankan karena dianggap telah mempunyai jaringan luas dan sumber dana yang besar. Namun demikian, di lapangan dapat ditemukan beberapa instansi yang bertugas sebagai pelaksana/ penyalur suatu kredit seperti Lembaga Keuangan Mikro (LKM) dan Lembaga Pengelola Dana Bergulir (LPDB) atau Badan Layanan Umum (BLU) lainnya. Pada kesempatan ini penulis akan memaparkan secara singkat beberapa alternatif instansi pelaksana/penyalur yang dapat ditugaskan oleh pemerintah dalam mendukung pelaksanaan kredit program dimaksud.

\section{Lembaga Keuangan Mikro}

Berdasarkan Undang-undang No. 1 Tahun 2013 tentang Lembaga Keuangan Mikro, bentuk dan badan hukum LKM adalah Perseroan Terbatas (PT) atau koperasi. Apabila berbentuk PT, maka sumber modalnya adalah 60 persen dari pemkab/ pemkot/Badan Usaha Milik Desa (BUMDes) dan sisanya adalah dari WNI dan koperasi maksimal 40 persen. Sedangkan jika berbentuk koperasi, sumber modalnya adalah berasal dari simpanan wajib, 
simpanan pokok, dan hibah. LKM harus memiliki izin usaha dari Otoritas Jasa Keuangan (OJK). Oleh karena itu, pembinaan, pengaturan, dan pengawasan LKM dilakukan oleh OJK. Dalam hal pembinaan dan pengawasan dapat didelegasikan ke pemkab/pemkot atau pihak yang ditunjuk.

Kegiatan inti LKM, yaitu (1) pinjaman/pembiayaan usaha skala mikro kepada anggota dan masyarakat, (2) pengelolaan simpanan, (3) pemberian jasa konsultasi pengembangan usaha. Apabila diperlukan, pemerintah bersama pemda dan LKM dapat mendirikan lembaga penjamin simpanan untuk LKM. Selain itu, LKM wajib bertransformasi menjadi bank jika kegiatan usahanya melebihi satu wilayah kabupaten/kota tempat kedudukan LKM.

\section{LPDB dan BLU Lainnya}

Sesuai dengan Peraturan Pemerintah No. 23 Tahun 2005 tentang Pengelolaan Keuangan Badan Layanan Umum, pemerintah dapat membentuk sebuah institusi yang ditujukan untuk memberikan pelayanan kepada masyarakat tanpa mengutamakan mencari keuntungan dengan tetap mempertahankan prinsip efisiensi dan produktivitas dalam melaksanakan kegiatannya. Institusi tersebut adalah BLU yang memiliki fleksibilitas menerapkan praktik-praktik bisnis yang sehat untuk meningkatkan pelayanan umum kepada masyarakat.

Terkait dengan pengembangan koperasi, usaha mikro, kecil, dan menengah (KUMKM), pemerintah telah membentuk LPDB pada tahun 2008. LPDB KUMKM merupakan BLU yang berada di bawah naungan Kementerian Koperasi dan Usaha Kecil dan Menengah. Dana bergulir tersebut ditujukan untuk penguatan modal usaha koperasi, usaha mikro, kecil, dan menengah dan disalurkan kepada masyarakat, ditagih dengan/tanpa nilai tambah dan digulirkan kembali kepada masyarakat. Dana bergulir yang dikelola dapat disalurkan melalui Lembaga Keuangan Bank (LKB), Lembaga Keuangan Bukan Bank (LKKB), dan BLU Daerah (BLUD). LKB dan LKKB dapat berperan sebagai penyalur (channeling) maupun pelaksana pengguliran (executing), sedangkan koperasi/LKM dapat berperan sebagai pelaksana pengguliran (executing).

LPDB KUMKM menyalurkan dana bergulir kepada penerimanya melalui beberapa mekanisme penyaluran, yaitu sebagai berikut:

1) LPDB KUMKM $\rightarrow$ Koperasi $\rightarrow$ Penerima

2) LPDB KUMKM $\rightarrow$ Lembaga Keuangan Bank (LKB) /Lembaga Keuangan Bukan Bank (LKBB) $\rightarrow$ Penerima

3) LPDB KUMKM $\rightarrow$ Penerima

Berdasarkan skema tersebut, beberapa lembaga penyalur dana bergulir KUMKM adalah koperasi
Tabel 3. Kinerja LPDB KUMKM

\begin{tabular}{rrrr}
\hline Tahun & $\begin{array}{c}\text { Jumlah } \\
\text { UMKM } \\
\text { (UMKM) }\end{array}$ & $\begin{array}{c}\text { Jumlah } \\
\text { Tenaga Kerja } \\
\text { (Orang) }\end{array}$ & $\begin{array}{c}\text { Jumlah Dana Bergulir } \\
\text { di Mitra (Rp) }\end{array}$ \\
\hline 2008 & 3.820 & 7.642 & 35.125 .000 .000 \\
\hline 2009 & 30.246 & 43.005 & 197.652 .109 .986 \\
\hline 2010 & 53.379 & 89.271 & 410.293 .458 .246 \\
\hline 2011 & 114.822 & 212.157 & 975.085 .402 .039 \\
\hline 2012 & 125.340 & 233.192 & 1.071 .762 .493 .000 \\
\hline 2013 & 163.969 & 310.450 & 1.426 .845 .231 .700 \\
\hline 2014 & 137.793 & 251.078 & 1.153 .968 .001 .560 \\
\hline 2015 & 186.733 & 340.253 & 1.563 .820 .224 .530 \\
\hline Jumlah & 816.102 & 1.487 .048 & 6.834 .551 .921 .061 \\
\hline
\end{tabular}

Sumber: Kemenkop dan UKM, 2015.

(koperasi simpan pinjam, unit simpan pinjam koperasi primer, dan koperasi sekunder), bank, LKBB, dan perusahaan modal ventura. Pada setiap skema tersebut, besarnya tingkat bunga yang dikenakan kepada lembaga penyalur maupun penerima ditetapkan melalui Peraturan Menteri Keuangan sebagai tarif layanan BLU.

Pada periode tahun 2008-2015, LPDB KUMKM telah menyalurkan dana bergulir sebanyak Rp6,8 triliun kepada 816.102 UMKM. Sementara itu, jumlah tenaga kerja yang dapat diserap oleh UMKM tersebut adalah sebanyak 1.487.048 orang. Terkait dengan performa pinjaman dari para debitur, sampai dengan akhir tahun 2014 terdapat tunggakan sebesar Rp219 miliar atau 5,5 persen dari total plafond.

Sebagai salah satu institusi penyalur kredit kepada KUMKM, LPDB KUMKM memiliki beberapa kelebihan. Pertama, LPDB KUMKM telah memiliki data mitra maupun penerima kredit yang tersebar di seluruh Indonesia. Adanya data tersebut dapat memastikan ketepatan sasaran pemberian kredit program dari pemerintah. Kedua, mitra LPDB KUMKM telah tersebar di seluruh provinsi di Indonesia. Ketiga, besarnya suku bunga yang dikenakan LPDB KUMKM kepada penyalur maupun penerima ditetapkan oleh Menteri Keuangan sebagai tarif layanan BLU. Hal ini memungkinkan pemerintah untuk memberikan subsidi secara implisit kepada penerima pinjaman melalui tarif layanan yang lebih rendah dari bunga pasar dengan tetap mempertimbangkan prinsip efisiensi dan efektivitas dari kredit program tersebut. Keempat, salah satu mitra penyalur utama pinjaman LPDB KUMKM adalah koperasi. Berdasarkan Undang-Undang LKM, salah satu bentuk badan usaha yang diizinkan untuk beroperasi sebagai LKM adalah koperasi. Melalui LPDB KUMKM, pemerintah dapat berperan untuk memperkuat kelembagaan koperasi sehingga nantinya dapat berfungsi sebagai 
LKM yang memberikan jasa keuangan mikro kepada masyarakat khususnya masyarakat miskin dan rentan miskin. Pemberian subsidi secara implisit dapat diberikan dengan tujuan untuk pembangunan infrastruktur dan penguatan kelembagaan koperasi yang akan menjadi LKM pada tahap awal pendirian LKM tersebut. Dengan demikian, subsidi yang diberikan pemerintah dalam kurun waktu akan efisien, tepat sasaran, dan pada akhirnya dapat menghindari adanya ketergantungan pada subsidi.

Di samping kelebihan tersebut terdapat pula beberapa kelemahan dari LPDB KUMKM yang perlu dipertimbangkan. Pertama, jumlah dana bergulir yang disalurkan melalui LPDB KUMKM relatif kecil apabila dibandingkan dengan dana yang mampu disediakan oleh perbankan. Sampai dengan tahun 2015, jumlah dana bergulir yang mampu disalurkan adalah sebesar Rp5 triliun. Jumlah tersebut sangatlah kecil apabila dibandingkan dengan kemampuan bank seperti BRI misalnya yang mampu menyalurkan KUPS/KKP-E sebesar Rp30 triliun dalam waktu 1 tahun. Kedua, LPDB KUMKM tidak memiliki perwakilan di setiap daerah sehingga tidak menutup kemungkinan munculnya kendala dalam pengawasan penyaluran pinjaman. Ketiga, berdasarkan pengalaman sebelumnya, kredit program dari pemerintah tidak pernah lepas dari risiko moral hazard dari para debitur. Oleh karena itu, desain insentif yang tepat sangatlah diperlukan untuk meminimalkan risiko moral hazard. Keempat, pemberian pinjaman kepada UMKM harus disertai dengan pendampingan kepada para penerimanya sehingga pinjaman tersebut digunakan dengan tepat dan mendukung produktivitas dari UMKM. Pemerintah harus memastikan bahwa mereka yang mendapatkan pinjaman adalah mereka yang layak dari sisi kemauan dan kemampuan dalam berusaha, sehingga dana yang diberikan tidak terbuang sia-sia. Selain itu, perlu diperhatikan pula adakah program pengentasan kemiskinan lain yang kemungkinan akan tumpang tindih dengan kredit program yang disalurkan oleh pemerintah agar program yang dilaksanakan terjamin efisiensi dan efektivitasnya.

\section{Bank}

Bank merupakan salah satu lembaga keuangan formal yang dapat menghimpun dana dari masyarakat dalam jumlah besar untuk kemudian disalurkan kembali kepada masyarakat dalam bentuk pinjaman. Terkait dengan kredit program, beberapa bank khususnya bank BUMN telah terlibat dalam penyaluran kredit program mulai dari BIMAS, KUT, KKP, KKP-E, KPEN-RP, KUPS, KUR, sampai dengan S-SRG. Skema yang diberikan dalam kredit program sebagian besar adalah melalui subsidi bunga, hanya KUR yang menggunakan skema penjaminan.
Meskipun telah berlangsung dalam jangka waktu yang sangat panjang, kredit program melalui bank sarat dengan kendala dan permasalahan dalam pelaksanaannya. Masalah klasik, yaitu moral hazard yang berujung pada membengkaknya non performing loan (NPL) menjadi salah satu penyebab gagalnya Bimbingan Massal (Bimas) dan Kredit Usaha Tani (KUT) pada masa yang lalu. Adanya pengalaman buruk di masa lalu berimbas pada semakin tingginya tingkat kehati-hatian bank dalam menyalurkan kredit program. Kehati-hatian tersebut berimbas pada rendahnya penyerapan kredit program dengan skema subsidi bunga, seperti KKP-E, KUPS, dan S-SRG. Sementara itu, untuk kredit program dengan skema penjaminan, seperti KUR memiliki penyerapan yang relatif lebih baik. Lebih baiknya penyerapan kredit program dengan skema penjaminan ini membuktikan bahwa bank memiliki akses informasi yang terbatas terhadap calon debiturnya sehingga bank enggan menyalurkan kredit, kecuali jika debitur memiliki kelayakan jaminan sesuai dengan apa yang dipersyaratkan.

Bank memiliki beberapa kelebihan dari bank sebagai penyalur kredit program. Pertama, bank memiliki kemampuan untuk menghimpun dana dari masyarakat dalam jumlah besar. Kedua, bank telah memiliki sistem kerja dan standar operasi yang terstruktur sehingga memiliki kemampuan manajemen yang relatif baik dalam mengelola usaha keuangan.

Terkait dengan pemberian kredit program, bank memiliki beberapa kelemahan. Pertama, risiko moral hazard dan keterbatasan informasi menimbulkan tingkat kehati-hatian yang tinggi seperti persyaratan jaminan dengan nilai besar. Kedua, bank merupakan lembaga keuangan formal yang berorientasi untuk memaksimalkan keuntungan. Ketiga, tidak semua bank memiliki jaringan cabang yang menjangkau seluruh pelosok tanah air, kecuali BRI dengan unit desanya yang telah tersebar hingga ke perdesaan. Sebagian besar masyarakat miskin tinggal di daerah perdesaan sedangkan bank sebagian besar beroperasi di daerah perkotaan sehingga akan muncul tambahan biaya yang timbul dari jarak antara keduanya apabila masyarakat desa ingin mendapatkan layanan keuangan dari bank.

Dana yang telah disalurkan oleh perbankan kepada UMKM jumlahnya jauh lebih besar apabila dibandingkan dengan LPDB KUMKM. Berdasarkan data dari Bank Indonesia, sampai dengan bulan April 2015 jumlah kredit yang telah disalurkan kepada UMKM mencapai Rp725,2 triliun. Jumlah ini sangat jauh dari kredit yang telah disalurkan oleh LPDB KUMKM pada periode yang sama yaitu hanya sebesar Rp6 triliun. Sementara itu, net ekspansi dari kredit 
perbankan yang diberikan kepada UMKM berkisar pada Rp60 sampai dengan Rp80 triliun per tahunnya.

\section{B. Pembahasan}

Setelah memerhatikan uraian tersebut maka secara singkat dapat dipaparkan kelebihan dan kekurangan dari ketiga instansi tersebut seperti pada Tabel 5.

\section{Bank}

Selama ini kredit program selalu disalurkan melalui perbankan baik skema penjaminan maupun skema subsidi bunga dalam hal ini adalah program KUR seperti yang terlihat pada Gambar 3.

Skema penyaluran inilah yang selama ini dilakukan dalam rangka menyukseskan kredit program khususnya program KUR yaitu dengan melibatkan perbankan dan perusahaan penjamin untuk skema langsung dan melibatkan koperasi/poktan/gapoktan/ lainnya sebagai lembaga linkage jika penyalurannya dilakukan tidak langsung. Pada beberapa jenis kredit program, penyaluran kredit dianggap sangat kecil disebabkan karena faktor kehati-hatian bank yang sangat tinggi kepada calon debitur sehingga ada wacana untuk mencari alternatif lembaga penyalur lainnya.

\section{LPDB atau BLU Lainnya}

Seperti yang disebutkan sebelumnya bahwa LPDB merupakan satuan kerja BLU pengelola dana bergulir di bawah Kementerian Koperasi dan UKM. Dana bergulir tersebut ditujukan untuk penguatan modal usaha koperasi, UMKM, dan disalurkan kepada masyarakat, ditagih dengan/tanpa nilai tambah dan digulirkan kembali kepada masyarakat. Dana bergulir yang dikelola dapat disalurkan melalui Lembaga
Tabel 4. Kredit yang Disalurkan Bank kepada UMKM

(Rp milliar)

\begin{tabular}{lccccc}
\hline Tahun & 2011 & 2012 & 2013 & 2014 & 2015* \\
\hline $\begin{array}{l}\text { Baki } \\
\text { Debit }\end{array}$ & 479.887 & 552.226 & 639.471 & 707.462 & 725.190 \\
\hline $\begin{array}{l}\text { Net } \\
\text { Ekspansi }\end{array}$ & 85.588 & 72.339 & 87.245 & 67.990 & 17.729 \\
\hline
\end{tabular}

Keterangan: *sampai dengan bulan April 2015.

Sumber: Bank Indonesia, 2015 (diolah).

Keuangan Bank (LKB), Lembaga Keuangan Bukan Bank, dan BLU Daerah. Ada 3 cara penyaluran dana bergulir yang dilakukan oleh LPDB selama ini, yaitu:

a. disalurkan secara langsung kepada koperasi dan UMKM;

b. disalurkan melalui lembaga perantara berupa bank dan LKBB dengan pola executing di mana lembaga perantara tersebut mempunyai tanggung jawab menyeleksi dan menetapkan penerima debitur, menyalurkan dan menagih kembali dana bergulir, dan menanggung risiko terhadap ketidaktertagihan dana bergulir;

c. disalurkan melalui lembaga perantara berupa bank, LKBB, dan satuan kerja pemerintah daerah (pemda) dengan pola channeling di mana lembaga perantara tersebut hanya menyalurkan dan menagih kembali dana bergulir dari/ke debitur, tidak bertanggung jawab menetapkan penerima dana bergulir, dan tidak menanggung risiko terhadap ketidaktertagihan dana bergulir.

Sedangkan BLU lainnya adalah BLU-BLU yang berada di bawah kementerian/lembaga lainnya yang diharapkan dapat berperan sebagai penyalur kredit program pada masa yang akan datang meskipun hal

Tabel 5. Perbandingan Institusi Penyalur Kredit Program

\begin{tabular}{|c|c|c|c|}
\hline No & Institusi & Kelebihan & Kelemahan \\
\hline 1. & Bank & $\begin{array}{l}\text { 1. Sumber dana besar } \\
\text { 2. Sistem telah terbangun } \\
\text { 3. Jaringan luas }\end{array}$ & $\begin{array}{l}\text { 1. Profit oriented } \\
\text { 2. Bunga ditentukan pasar } \\
\text { 3. Prudentiality sangat tinggi }\end{array}$ \\
\hline 2. & $\begin{array}{l}\text { Lembaga Keuangan Mikro } \\
\text { (LKM) }\end{array}$ & $\begin{array}{l}\text { 1. Lebih dekat dengan sasaran } \\
\text { (s.d pedesaaan) } \\
\text { 2. Sekitar } 631.867 \text { unit di } \\
\text { seluruh Indonesia } \\
\text { 3. Tunduk pada aturan OJK } \\
\text { 4. Ada dua skema pinjaman: } \\
\text { konvensional dan syariah }\end{array}$ & $\begin{array}{l}\text { 1. Sumber dana terbatas dan akumulasi modal } \\
\text { belum terdeteksi } \\
\text { 2. Aturan pinjaman terlalu rigit } \\
\text { 3. Perlu pembinaan SDM LKM yang sangat intensif } \\
\text { jika instansi ini sebagai pelaksana }\end{array}$ \\
\hline 3. & $\begin{array}{l}\text { Lembaga Pengelola Dana } \\
\text { Bergulir (LPDB) atau BLU } \\
\text { lainnya }\end{array}$ & $\begin{array}{l}\text { 1. Tidak profit oriented } \\
\text { 2. Suku bunga diatur oleh } \\
\text { pemerintah (Menkeu) } \\
\text { 3. Untuk LPDB sudah ada } \\
\text { 4. Untuk BLU, tersebar di daerah } \\
\text { meskipun dengan jumlah } \\
\text { yang relatif kecil (BLUD) }\end{array}$ & $\begin{array}{l}\text { 1. Sumber dana terbatas (APBN K/L) } \\
\text { 2. Mayoritas BLU/BLUD fokus di bidang kesehatan } \\
\text { dan pendidikan bukan keuangan } \\
\text { 3. Perlu waktu lama untuk menyesuaikan tugas } \\
\text { dan fungsi/sistem kerja SDM BLU dan perlu } \\
\text { dilakukan pembinaan SDM LKM yang sangat } \\
\text { intensif jika instansi ini sebagai pelaksana }\end{array}$ \\
\hline
\end{tabular}

Sumber: berbagai sumber (diolah). 
1. Langsung dari Bank Pelaksana ke UMKMK

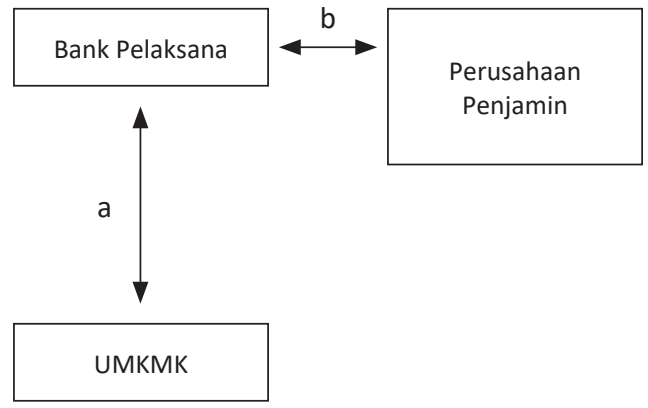

Sumber: TNP2K, tidak ada tahun.

Gambar 3a. Penyaluran Kredit Program melalui Bank Secara Langsung

ini sangat sulit diwujudkan karena tugas pokok, fungsi, dan karakter pekerjaan BLU pada umumnya adalah berlainan sekali dengan BLU yang berfungsi sebagai lembaga penyalur kredit/dana bergulir seperti LPDB. Oleh karena itu penulis merekomendasikan bahwa penggunaan BLU (dalam hal ini LPDB) adalah bersifat sementara (short term) atau sebagai bridging scheme (sebagaimana dipaparkan pada Gambar 4) dengan tujuan jangka panjangnya adalah memanfaatkan instansi LKM sebagai lembaga utama penyalur kredit program.

\section{Lembaga Keuangan Mikro}

Sebagaimana disebutkan sebelumnya bahwa bentuk dan badan hukum LKM adalah PT atau koperasi, apabila berbentuk PT maka sumber modalnya adalah 60 persen dari pemkab/pemkot/BUMDes dan sisanya adalah dari WNI dan koperasi maksimal 40 persen. Sedangkan jika berbentuk koperasi, sumber modalnya adalah berasal dari simpanan wajib, simpanan pokok, dan hibah.

Mengingat jumlah unit LKM yang begitu besar (631.867 unit) yang tersebar di seluruh Indonesia
2. Tidak langsung melalui Linkage dengan Pola Executing

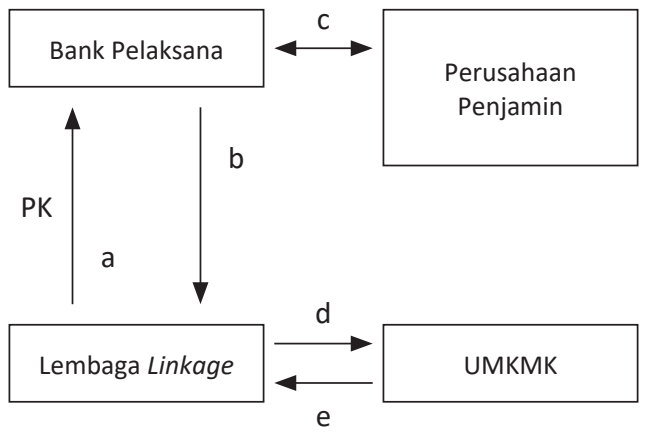

Sumber: TNP2K, tidak ada tahun.

Gambar 3b. Penyaluran Kredit Program melalui Bank dengan Lembaga Perantara

sampai pada tingkat kelurahan/perdesaan dan LKM juga harus berbadan hukum dan tunduk pada regulasi OJK, maka pemilihan LKM sebagai alternatif lembaga penyalur merupakan salah satu pilihan yang tepat untuk saat ini. LKM dapat berbentuk sebuah koperasi yang terdiri dari beberapa anggota koperasi. LKM dengan bentuk koperasi tentu memiliki akses informasi yang memadai terhadap calon debitur yang merupakan anggota dari koperasi tersebut. Group lending juga sangat memungkinkan untuk diterapkan oleh LKM untuk menghindari risiko default para debiturnya. Dengan demikian LKM yang berbentuk koperasi dapat dianggap memiliki karakteristik yang sama dengan Grameen Bank di Bangladesh. Adanya karakteristik tersebut diharapkan dapat mengatasi permasalahan adverse selection dan moral hazard dalam penerapan kredit program di Indonesia seperti saat ini. Selain itu, adanya penyertaan modal pemda setempat pada LKM diharapkan akan meningkatkan pembinaan dan pengawasan terhadap LKM yang ada di wilayahnya juga akan menambah kelayakan LKM dalam melaksanakan tugas ini. Hal lain yang menurut penulis termasuk penting dalam skema

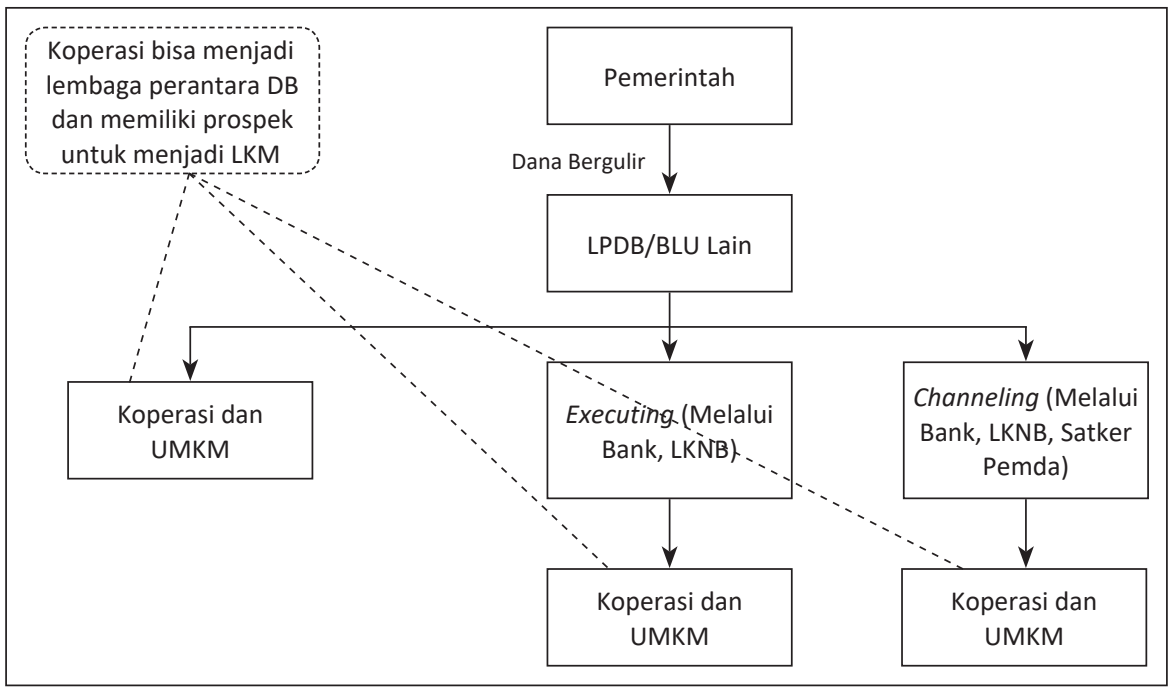

Sumber: Ilustrasi penulis.

Gambar 4. Penyaluran Kredit Program melalui LPDB/BLU (Bridging Scheme) 


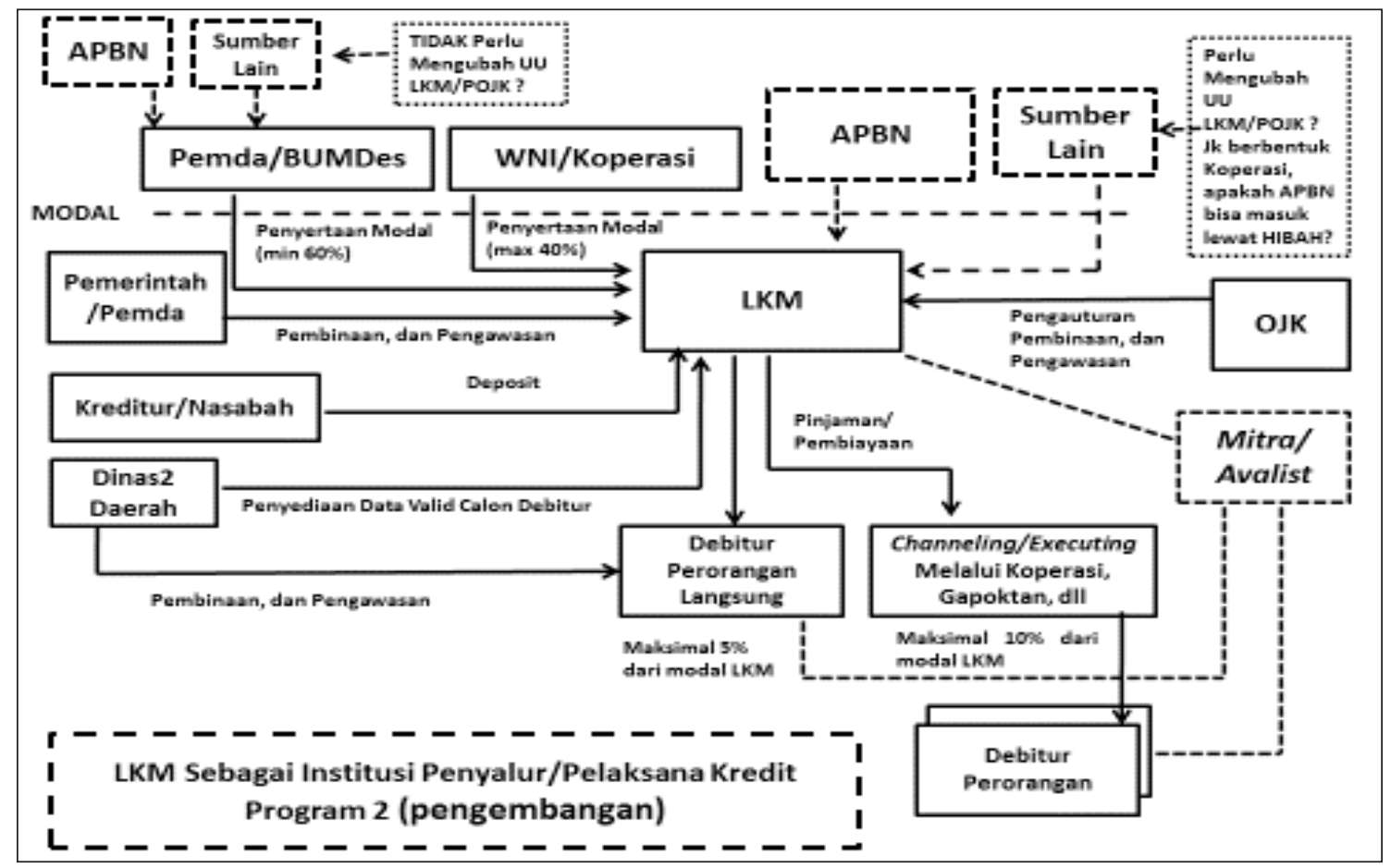

Keterangan: Garis tebal: hubungan koordinasi instansi utama.

Garis putus-putus: hubungan koordinasi instansi sekunder.

Kotak tebal: instansi wajib.

Kotak putus-putus: instansi penunjang.

Sumber: Ilustrasi penulis.

Gambar 5. Penyaluran Kredit Program melalui LKM

kredit program yang akan direkomendasikan adalah dengan melibatkan mitra atau avalist yang berfungsi membantu debitur kredit sebagai penjamin pinjaman jika terjadi default. Adapun kompensasi yang akan didapatkan avalist, misalnya adalah mendapat prioritas utama untuk membeli semua produk dari debitur yang dijamin tersebut dengan harga yang wajar.

Hanya saja yang perlu dipikirkan untuk memperlancar kredit program ini adalah bagaimana meningkatkan jumlah dana yang berada di LKM mengingat dalam Undang-Undang No. 1 Tahun 2013 tentang LKM disebutkan bahwa untuk LKM yang berbentuk PT maka hanya pemda/BUMDes dan WNI/koperasi yang dapat menanamkan modalnya. Sedangkan untuk LKM yang berbentuk koperasi maka sumber modalnya berasal dari simpanan wajib, simpanan pokok dari para anggotanya, dan hibah.

Oleh karena itu, jika pemerintah pusat sebagai pihak yang bertanggung jawab terhadap program ini dan pihak lain seperti swasta ingin terlibat dalam permodalan, maka rekomendasi penulis adalah dengan cara menanamkan modal lewat pemda dan atau BUMDes setempat atau memberikan hibah kepada koperasi yang berbentuk LKM tersebut. Cara lainnya adalah mengusulkan perubahan undangundang tersebut dan Peraturan OJK (POJK) agar pemerintah dan pihak lain bisa terlibat langsung dalam penyertaaan modal dan dapat menyuntikkan dana kepada LKM-LKM yang ditugaskan untuk menjalankan kredit program sehingga LKM mempunyai kapasitas modal yang besar dan jangkauan ke sasaran target juga akan bertambah besar/luas. Skema atau model dari kredit program di mana LKM adalah sebagai instansi pelaksananya dapat digambarkan pada Gambar 5.

Jadi, jika dibandingkan dengan LPDB/BLU lainnya maka LKM dianggap lebih siap jika ditunjuk sebagai lembaga pelaksana kredit program di masa yang akan datang karena:

a. keberadaan LKM telah menyebar di seluruh Indonesia (sekitar 631 ribu), berada di tingkat kecamatan ataupun desa sehingga bisa menjadi aset yang dapat dikontrol oleh masyarakat;

b. LKM mempunyai tugas fungsi pokok sebagai lembaga yang memberikan pinjaman dan pembiayaan kepada debitur;

c. keterlibatan pemda lebih dominan (sesuai Undang-Undang No. 1 Tahun 2013);

d. mekanisme pelaksanaan dapat dilakukan dengan dua alternatif prinsip pembiayaan, baik secara konvensional maupun syariah;

e. memiliki tujuan meningkatkan pemberdayaan ekonomi dan produktivitas masyarakat serta meningkatkan pendapatan dan kesejahteraan masyarakat;

f. harus tunduk pada aturan OJK; dan 
g. LPDB/BLU lainnya dianggap kurang siap karena infrastruktur tidak memadai dan tugas fungsi pokok BLU harus menginduk ke kementerian/lembaga atau pemda-nya masing sehingga tidak sesuai dengan visi/misi/karakter di bidang keuangan dan simpan pinjam.

Permasalahan dapat muncul dalam masa transisi perubahan penerapan skema kredit program. Oleh karena itu, beberapa opsi transisi perubahan skema penyaluran kredit program perlu untuk dipertimbangkan. Beberapa opsi tersebut diikhtisarkan pada Tabel 6.

Untuk saat ini pemberian bantuan pinjaman modal usaha yang paling memungkinkan adalah dengan menggunakan opsi I di mana pemerintah menetapkan target sasaran penerima bantuan pinjaman modal usaha berdasarkan basis data terpadu, yaitu pengusaha yang termasuk kategori miskin dan rentan miskin pada desil 1 sampai dengan 4 menurut pendapatan untuk kemudian disalurkan bantuan kredit modal usaha kepada mereka melalui LPDB dan koperasi. Mengingat pengusaha yang masuk dalam kategori miskin dan rentan miskin pada desil 1 sampai dengan 4 sulit untuk mendapatkan akses permodalan ke perbankan, dalam jangka panjang pemerintah dapat mempertimbangkan opsi II untuk mengembangkan/mengganti koperasi menjadi LKM, dengan pertimbangan bahwa LKM merupakan lembaga profesional yang harus tunduk

Tabel 6. Opsi Skema Kredit Program

\begin{tabular}{|c|c|c|}
\hline Opsi & Opsi I & Opsi II \\
\hline Skema & $\begin{array}{l}\text { LPDB } \rightarrow \text { Koperasi/LKM } \\
\rightarrow \text { penerima }\end{array}$ & LKM $\rightarrow$ penerima \\
\hline Sumber dana & Dana bergulir APBN & Dana masyarakat \\
\hline Pengelola & LPDB & LKM \\
\hline $\begin{array}{l}\text { Lembaga } \\
\text { penyalur }\end{array}$ & Koperasi/LKM & $\begin{array}{l}\text { Langsung atau } \\
\text { Koperasi non LKM/ } \\
\text { Poktan/ Gapoktan }\end{array}$ \\
\hline $\begin{array}{l}\text { Kelebihan/ } \\
\text { Keunggulan }\end{array}$ & $\begin{array}{l}\text { 1. Lembaga penyalur } \\
\text { tersebar di seluruh } \\
\text { daerah } \\
\text { 2. Besarnya suku } \\
\text { bunga diatur } \\
\text { melalui PMK } \\
\text { 3. Koperasi memiliki } \\
\text { prospek menjadi } \\
\text { LKM di masa datang }\end{array}$ & $\begin{array}{l}\text { 1. Sumber dana } \\
\text { berasal dari } \\
\text { masyarakat } \\
\text { 2. Membuka } \\
\text { ruang untuk } \\
\text { keterlibatan } \\
\text { pemda } \\
\text { 3. Ada supervisi } \\
\text { dari OJK }\end{array}$ \\
\hline $\begin{array}{l}\text { Kekurangan/ } \\
\text { Kelemahan }\end{array}$ & $\begin{array}{l}\text { 1. Jumlah dana } \\
\text { terbatas } \\
\text { 2. Kendala } \\
\text { pengawasan di } \\
\text { daerah } \\
\text { 3. Risiko moral hazard } \\
\text { 4. Diperlukan } \\
\text { pendampingan }\end{array}$ & $\begin{array}{l}\text { 1. Biaya dana } \\
\text { bisa lebih } \\
\text { besar } \rightarrow \\
\text { bunga tinggi } \\
\text { 2. Dibutuhkan } \\
\text { LKM yang } \\
\text { tangguh dan } \\
\text { mandiri }\end{array}$ \\
\hline
\end{tabular}

Sumber: Berbagai sumber (diolah). pada aturan OJK, memiliki izin usaha dan wilayah operasi yang jelas, serta keterlibatan pemda lebih dominan untuk mengembangkan usaha keuangan mikro yang berkelanjutan di Indonesia.

\section{Skema Alternatif Kredit Program}

Terdapat salah satu kelemahan mendasar pada kedua skema subsidi kredit program yang sebelumnya. Pertama, keberlanjutan kedua program tersebut perlu untuk diperhatikan lebih dalam. Subsidi sebaiknya diberikan dalam jangka waktu tertentu yang terbatas. Tidak adanya jangka waktu yang jelas akan menimbulkan risiko semakin besarnya subsidi yang akan ditanggung pemerintah di masa yang akan datang. Tentu pemerintah tidak ingin pengalaman buruk pemberian subsidi seperti subsidi BBM terulang kembali di masa yang akan datang. Selain itu, subsidi yang terus menerus diberikan juga tidak memberikan insentif bagi petani untuk tidak mengandalkan subsidi di masa selanjutnya. Subsidi dari pemerintah sebaiknya digunakan untuk kegiatan yang sifatnya produktif dan membawa eksternalitas positif seperti pembangunan infrastruktur dan penguatan kelembagaan.

Lebih lanjut, salah satu kendala mengapa kredit program dengan skema subsidi bunga adanya proses yang panjang dalam pengajuan pinjaman kredit program. Bagi para petani yang merupakan sasaran terbesar penerima subsidi bunga, ketepatan waktu penyaluran kredit merupakan hal yang sangat penting mengingat usaha tani juga bergantung pada faktor alam seperti curah hujan, sehingga lamanya proses pencairan dana akan menjadi kendala tersendiri bagi para petani. Apabila hal tersebut terjadi maka tidak menutup kemungkinan petani akan mengandalkan lembaga keuangan informal yang ada di sekitar mereka untuk memenuhi kebutuhan dana modal kerja.

Salah satu kunci untuk membantu para petani dan pengusaha UMKM dalam memenuhi kebutuhan modal untuk modal kerjanya adalah dengan meningkatkan penetrasi lembaga keuangan sehingga mampu menjangkau mereka hingga di seluruh wilayah Indonesia. Mengingat sebagian besar rumah tangga miskin tinggal di wilayah perdesaan, sementara sebagian besar lembaga keuangan formal saat ini berada di wilayah perkotaan, maka upaya pengembangan dan pemberdayaan lembaga keuangan di perdesaan untuk melayani masyarakat yang tinggal di daerah tersebut.

Pemberdayaan lembaga keuangan mikro menjadi salah satu cara untuk meningkatkan akses layanan keuangan bagi masyarakat khususnya mereka yang masuk dalam kategori miskin dan rentan miskin serta bagi mereka yang tinggal di wilayah perdesaan. Mekanisme yang tersedia saat ini adalah melalui pemberian dana bergulir kepada KUMKM yang dikelola oleh LPDB KUMKM di bawah koordinasi Kementerian 
Koperasi dan Usaha Kecil dan Menengah. Penyaluran dana bergulir melalui LPDB KUMKM saat ini dilakukan secara langsung kepada penerima maupun melalui beberapa lembaga penyalur seperti koperasi simpan pinjam/unit simpan pinjam koperasi, perusahaan modal ventura, bank, dan lembaga keuangan bukan bank.

Koperasi dapat menjadi salah satu jalan untuk meningkatkan akses layanan keuangan bagi masyarakat miskin dan mereka yang tinggal di daerah perdesaan. Koperasi memiliki potensi untuk menjadi LKM mengingat koperasi merupakan salah satu bentuk badan usaha LKM yang diizinkan menurut Undang-Undang LKM tahun 2013. Selain memberdayakan koperasi sebagai penyalur dana bergulir, pemerintah juga dapat membantu memperkuat kelembagaan koperasi sehingga mampu menjadi LKM yang mandiri di masa yang akan datang.

Subsidi yang diberikan pemerintah sebaiknya didesain untuk mengembangkan infrastruktur bagi pengembangan koperasi menjadi LKM di masa yang akan datang. Salah satu bentuk subsidi bagi LKM adalah melalui pinjaman bunga rendah kepada LKM untuk selanjutnya disalurkan kepada penerimanya. Namun pinjaman bunga rendah tersebut harus diberikan dalam jangka waktu yang terbatas dan ditujukan untuk memberikan kemudahan bagi LKM tersebut untuk memperkuat kelembagaannya. Dengan kata lain, subsidi yang diberikan nantinya ditujukan bagi pengembangan institusi LKM dan infrastruktur pendukungnya. LKM yang tangguh dan mandiri diharapkan dapat melakukan mobilisasi dana yang ada di masyarakat yaitu menghimpun dana dari masyarakat dalam bentuk simpanan untuk kemudian disalurkan kembali kepada masyarakat dalam bentuk kredit atau pinjaman.

Saat ini pemerintah telah memiliki Undang-Undang LKM dan peraturan pendukungnya. Tentunya ini

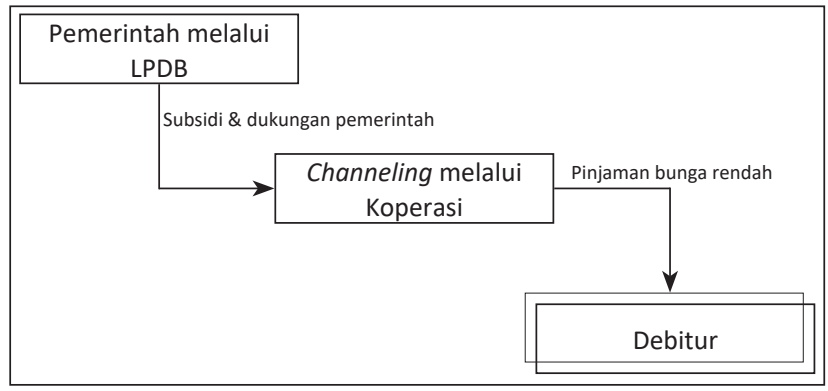

Sumber: Ilustrasi penulis.

Gambar 6. Alternatif Pola Penyaluran Kredit Program

sebuah awal yang baik untuk merubah pola pemberian subsidi kredit program dari subsidi kepada komoditas dalam hal ini kredit kepada subsidi kepada institusi penyalur kredit. Program seperti ini diharapkan dapat membantu mendukung tercapainya keuangan inklusif di Indonesia sehingga nantinya dapat mendukung produktivitas masyarakat sekaligus mengurangi angka kemiskinan.

Seperti telah dipaparkan pada Tabel 1 bahwa pada pelaksanaan kredit program existing ada 2 skema pemberian subsidi yang diatur oleh pemerintah, yaitu skema penjaminan dan skema subsidi bunga. Pada skema model kredit program tersebut, penulis juga merekomendasikan skema subsidi bunga yang bersifat terbatas dan tergantung pada jenis usaha debitur dan jenis komoditas yang digarap jika calon debitur berada di sektor pertanian karena variasi usaha dan jenis komoditas pertanian dapat menjadi pertimbangan pemilihan jenis dan besaran subsidi. Pada kajian ini juga diberikan alternatif subsidi kepada penyalur/pelaksana kredit program yang dalam hal ini adalah koperasi sebagai lembaga perantara jika pemerintah benar-benar akan memilih LKM atau BLU sebagai penyalur/ pelaksana kredit program tersebut.

Tabel 7. Perbandingan Beberapa Skema Subsidi Kredit Program

\begin{tabular}{|c|c|c|c|}
\hline & Skema Penjaminan & Skema Subsidi Bunga & Skema Subsidi Kepada Instansi Penyalur \\
\hline $\begin{array}{l}\frac{c}{\pi} \\
\frac{c}{0} \\
\frac{0}{d} \\
\frac{0}{d}\end{array}$ & $\begin{array}{l}\text { 1. Tetap memberikan akses kepada } \\
\text { unit usaha yang tidak memiiliki } \\
\text { agunan } \\
\text { 2. Risiko fiskal dari fluktuasi bunga } \\
\text { tidak ada } \\
\text { 3. Bank menurunkan prudentiality- } \\
\text { nya sehingga biasanya penyerapan } \\
\text { kredit tinggi }\end{array}$ & $\begin{array}{l}\text { 1. Suku bunga yang ditanggung } \\
\text { debitur lebih rendah } \\
\text { 2. Dapat meminimalkan moral } \\
\text { hazard } \\
\text { 3. Bank meningkatkan } \\
\text { prudentiality-nya sehingga } \\
\text { penyerapan kredit tinggi }\end{array}$ & $\begin{array}{l}\text { 1. Bunga yang ditanggung debitur bisa } \\
\text { lebih rendah karena institusi perantara } \\
\text { (koperasi) diberikan subsidi bunga oleh } \\
\text { pemerintah } \\
\text { 2. Memudahkan kerja LKM/BLU yang } \\
\text { ditunjuk karena koperasi yang mencari } \\
\text { debitur, menagih pinjaman debitur }\end{array}$ \\
\hline 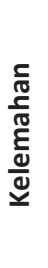 & $\begin{array}{l}\text { 1. Suku bunga debitur lebih tinggi } \\
\text { 2. Adanya potensi moral hazard } \\
\text { pada debitur untuk tidak melunasi } \\
\text { pinjamannya karena sudah ada } \\
\text { jaminan pemerintah }\end{array}$ & $\begin{array}{l}\text { 1. Fluktuasi suku bunga pasar } \\
\text { berpotensi menimbulkan } \\
\text { risiko fiskal } \\
\text { 2. Program subsidi ini akan } \\
\text { cenderung bersifat permanen } \\
\text { (sulit meningkatkan status } \\
\text { debitur agar terlepas) }\end{array}$ & $\begin{array}{l}\text { 1. Potensi moral hazard pada institusi } \\
\text { perantara dapat diminimalkan melalui } \\
\text { lembaga pengawas (LPDB) } \\
\text { 2. Adanya potensi salah sasaran/target } \\
\text { debitur sekedar untuk memperbanyak } \\
\text { debitur sehingga koperasi dapat subsidi } \\
\text { dari pemerintah lebih besar }\end{array}$ \\
\hline
\end{tabular}

Sumber: Berbagai sumber (diolah). 
Beberapa poin penting tentang skema pemberian subsidi pada kredit program yang penulis rekomendasikan adalah seperti dipaparkan pada Tabel 7.

\section{SIMPULAN DAN SARAN}

\section{A. Simpulan}

Berbagai jenis kredit program telah diterapkan di Indonesia dengan tujuan untuk memperluas akses keuangan bagi masyarakat khususnya mereka yang berpendapatan rendah. Selama ini program tersebut dilaksanakan oleh bank pelaksana yang ditunjuk oleh pemerintah melalui 2 skema, yaitu subsidi bunga dan penjaminan. Namun, penerapan program tersebut tidak terlepas dari permasalahan mendasar pada credit market, yaitu adverse selection dan moral hazard. Masalah pertama akan menyebabkan kehatihatian pihak bank terhadap calon debitur, sedangkan masalah kedua akan menyebabkan kredit tersebut dimanfaatkan oleh orang yang tidak berhak atau tidak tepat. Kedua masalah tersebut secara tidak langsung berkontribusi pada rendahnya penyerapan kredit program oleh masyarakat dan tetap rendahnya akses permodalan bagi masyarakat.

Berdasarkan hasil evaluasi, perubahan skema dan institusi penyalur kredit program menjadi salah satu solusi untuk meningkatkan akses permodalan bagi masyarakat dengan keterbatasan ekonomi. LKM dianggap dapat meminimalkan risiko akibat kedua permasalahan dasar tersebut. LKM, khususnya yang berbentuk koperasi memiliki akses informasi yang baik terhadap calon debitur yang merupakan anggota dari koperasi tersebut, sehingga permasalahan terkait adverse selection dan moral hazard dapat diminimalkan. Dalam skema ini terdapat pula supervisi dari lembaga pengawas, seperti LPDB, sehingga dapat meminimalkan adanya moral hazard dari lembaga penyalur itu sendiri.

Berkembangnya LKM akan mendukung terciptanya sebuah pasar permodalan yang efisien bagi masyarakat dengan keterbatasan ekonomi, khususnya mereka yang sedang menjalankan usaha. Dengan demikian, akses permodalan bagi masyarakat berpenghasilan rendah dapat ditingkatkan dan dapat membantu mereka untuk terhindar dari garis kemiskinan.

\section{B. Saran}

Pemerintah dapat menggunakan sumber daya yang tersedia saat ini untuk membantu mengembangkan LKM di Indonesia. Penguatan LKM dapat diberikan melalui skema dana bergulir yang telah dijalankan melalui LPDB-KUMKM. Melalui skema tersebut pemerintah dapat memberikan dukungan permodalan dan sumber dana dengan biaya rendah untuk mendukung pengembangan LKM menjadi sebuah lembaga keuangan mandiri di masa yang akan datang. Apabila LKM tersebut telah beroperasi dengan efisien, maka dukungan pemerintah tersebut dapat dialihkan kembali untuk mendukung pertumbuhan LKM lainnya sehingga dana tersebut tetap bergulir di masyarakat tanpa harus menambah beban fiskal pemerintah.

Akan tetapi, terdapat hal lain yang juga perlu untuk diperhatikan, yaitu pendampingan pemerintah, baik kepada debitur maupun LKM dalam implementasi program tersebut. Pendampingan tersebut sangat penting untuk memastikan bahwa kedua pihak tersebut telah menjalankan usahanya dengan memerhatikan prinsip efisiensi sehingga dana yang digunakan dapat memberikan manfaat yang optimal bagi keduanya.

\section{DAFTAR PUSTAKA}

\section{Buku}

Adams, D. W., Graham, D. H., \& Pischke, J. V. (1984). Undermining rural development with cheap credit. Boulder: Westview Press.

Armendariz de Aghion, B. \& Morduch, J. (2005). The economics of microfinance. Cambridge: The MIT Press.

Banerjee, A. (2003). Contracting constraints, credit markets and economic development. Advances in economics and econometrics, theory and application, eight world congress, Vol. 3. Cambridge: Cambridge University Press.

Karlan, D. \& Morduch, J. (2009). Access to finance. Handbook of Development Economics, Vol. 5. North Holland: Elsevier.

\section{Jurnal}

Aghion, P. \& Bolton P. (1997). A theory of trickledown growth and development. Review of Economic Studies, 64 (2), 151-172.

Ashari. (2009). Optimalisasi kebijakan kredit program sektor pertanian di Indonesia. Analisa Kebijakan Ekonomi, 7(1), 21-42.

Banerjee, A. \& Newman, A. (1993). Occupational choice and the process of development. Journal of Political Economy, Vol. 101, 274-298. 
Burgess, R. \& Pande, R. (2005). Do rural banks matter? Evidence from the Indian Social Banking experiment. The American Economic Review, 95(3), 780-795.

Mainsah, E., Heuer, S. R., Kalra, A., \& Zhang, Q. (2004). Grameen Bank: Taking capitalism to the poor. Chazen Web Journal of International Business, Spring 2004, 1-28.

Swain, R. B. (2002). Credit rationing in rural India. Journal of Economic Development, 27(2), 1-20.

\section{Sumber Digital}

Bank Indonesia. (2015). Statistik perbankan Indonesia. Diperoleh tanggal 10 Agustus 2015, dari http:// www.bi.go.id/id/statistik/perbankan/indonesia/ Pages/spi_0415.aspx.

TNP2K. (Tidak ada tahun). Program Kredit Usaha Rakyat (KUR). Diperoleh tanggal 30 Agustus 2016, dari http://www.tnp2k.go.id/id/tanyajawab/klaster-iii/progam-kredit-usaha-rakyatkur/.

\section{Sumber lainnya}

Arifin, B. (2013). Best practice kredit sektor pertanian, FGD Penyusunan Model Penyerapan Kredit Sektor Pertanian. BKF-Kementerian Keuangan, Jakarta.

Aziz, A. (2013). Upaya optimalisasi penyerapan kredit sektor pertanian. Majalah Info Risiko Fiskal, Edisi 2. Jakarta: Kementerian Keuangan, 17-22.

Kemenkop dan UKM. (2015). Laporan Tahunan Kementerian Koperasi dan UKM Tahun 2015. Jakarta: Kemenkop dan UKM, 1-122.

Tim Pelaksana Komite Kebijakan Penjaminan Kredit/ Pembiayaan Kepada Usaha Mikro, Kecil, Menengah, dan Koperasi. (2012). Standar operasional dan prosedur pelaksanaan Kredit Usaha Rakyat (SOPKUR). Jakarta: Kementerian Koordinator Bidang Perekonomian RI. 